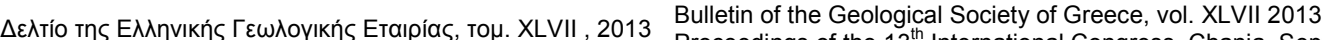
Proceedings of the $13^{\text {th }}$ International Congress, Chania, Sept.

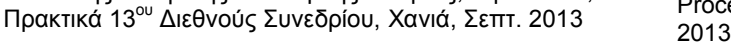

\title{
THE ROLE OF KEFALOVRUSO AND AMOURIO SPRINGS IN THE HYDRODYNAMIC CONDITIONS OF POTAMIA ELASSONA BASIN
}

\author{
Vasileiou E. ${ }^{1}$ and Koumantakis $\mathbf{I}^{1}$ \\ ${ }^{I}$ National Technical University of Athens, School of Mining Engineering \& Metallurgy, Section of \\ Geological Sciences, Laboratory of Engineering Geology \& Hydrogeology, \\ Iroon Polytechneiou 9, Zografou Campus, Athens 15780 \\ elvas@metal.ntua.gr,koumantakisioannis@gmail.com,
}

\begin{abstract}
Two lignite deposits have been found in the Neogene basin of Potamia, located in Elassona area in central Greece. The water resources of the region affect critically the exploitation of the mineral deposits. The detailed hydrogeological research of the area is imperative before starting the mining activities. Two groups of springs discharge near the study area. The karstic springs of Kefalovruso are in the northwest boundaries of the Neogene basin and the springs of Amourio are located in the Quaternary alluvial deposits, in the central part of the area. This paper includes the analysis of the hydrogeological conditions of the springs, the processing of the water-measurements (water supply, water level) and their correlation with the area's meteorological data. The time series of hydrological data, from 1972 to 2008, were evaluated for both springs and several parameters were estimated in order to investigate the function and the capacity of the springs. The relation between the recharge system of the springs and the area's groundwater dynamics is also analysed. Key words: karstic, hydrogeology, Thessaly, discharge, recharge.
\end{abstract}

\section{Пєрí $\lambda \psi \psi \eta$}

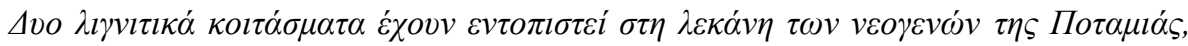

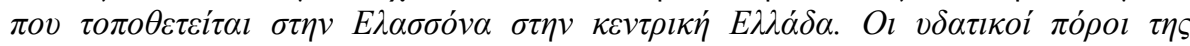

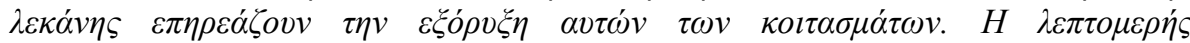

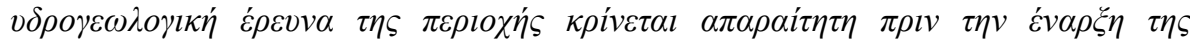

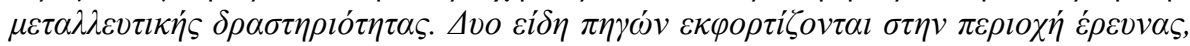

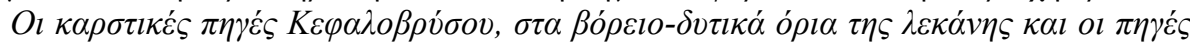

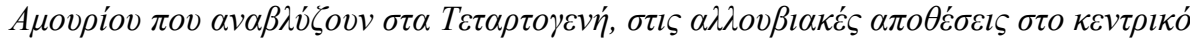

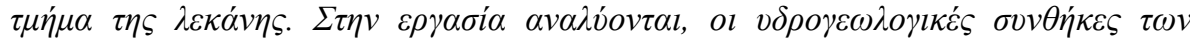

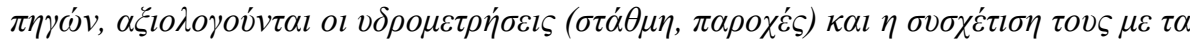

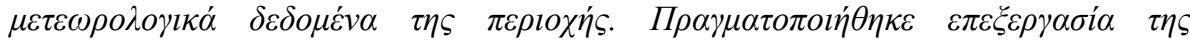

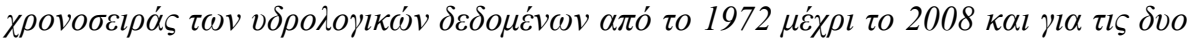

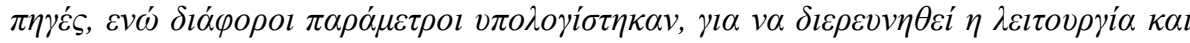

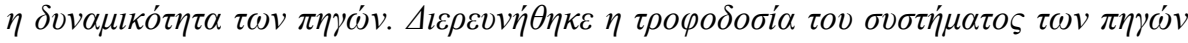

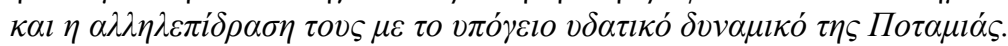

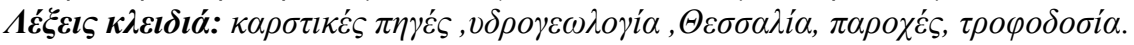

XLVII. No $2-801$ 


\section{Introduction}

Potamia basin is located in the municipality of Elassona, in Thessaly, Central Greece. In this basin, two lignite deposits of $187,5 \times 10^{6}$ tn (Domeniko $-167 \times 10^{6}$ th and Amourion- $20,5 \times 10^{6} \mathrm{tn}$ ) have been identified (Dimitriou 1997). Two significant springs of Amourio and Kefalovruso influence the hydrogeological conditions of Potamia basin. Amourio springs discharge alluvium aquifer, in an elongated forehead at elevation of $170 \mathrm{~m}$ asl. They adrain out, in two different sites, the first 1 $\mathrm{km}$ south-east of Magoula village and the second about 2,5 km north of Amourio village. According to Panila (1999), the discharge of Amourio springs caused by the development of lignite layers at a depth of 60 meter, the lignite deposit constitutes the barrier for the groundwater flow.

The high capacity karstic aquifer of Krania, is drained out by the significant karstic spring, which is located $800 \mathrm{~m}$ north of the Kefalovruso village. It is a front of springs about $30 \mathrm{~m}$ long, at an altitude of $255 \mathrm{~m}$.

The water of these two springs (Amourio and Kefalovruso) recharges the Quaternary sediments of the basin and covers irrigation and water supply needs for the wider area. Amourio springs are located at the western boundaries of the lignite deposits, thus the interaction of these springs with the mining activity is very interesting. Kefalovruso springs do not have direct hydraulic connection with the future lignite mine, but they affect the lignite exploitation via the recharge of the alluvial aquifer in the basin.

\section{Geology-Hydrogeology}

\subsection{Amourio Springs}

The alluvial aquifer is primarily replenished by recharge from the infiltration of Elassonitikos River and the percolation of the precipitation in the upstream alluvial area.

The rainfall through infiltration enriches the shallow unconfined aquifer and the deeper alluvial aquifers of Potamia (some of these deeper aquifers are confined or semi-confined).Groundwater flows under the bed of old streams, while the morphological slopes or the less impermeable formations force it to discharge on surface, via Amourio springs.

There is probably an additional supply to the springs from the karstic aquifers, which are developed in the marbles of Evagelistria and Paleokastro area (Figure 2). These marbles are hydrologically isolated from the main marble mass, which is developed at the north-west area of Kamvounia. There are no spring discharges in the surface of marbles and alluvial in the area of Evagelistria, which means that there is hydraulic underground connection between these formations and thus it recharges the alluvial deposits of Potamia and Amourio springs. Groundwater, from these marbles, flows downstream Elassonitikos River and ends up to the springs. Additional quantities from the river's infiltration must be considered.

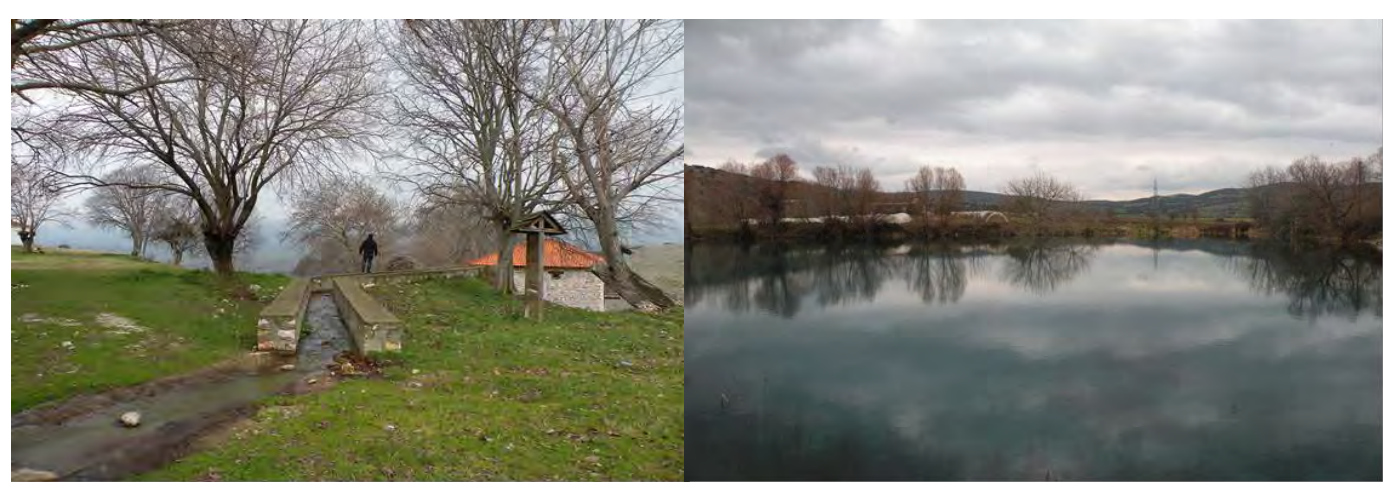

Figure 1 - Image of Amourio (on the left) and Kefalovruso (on the right) springs. 


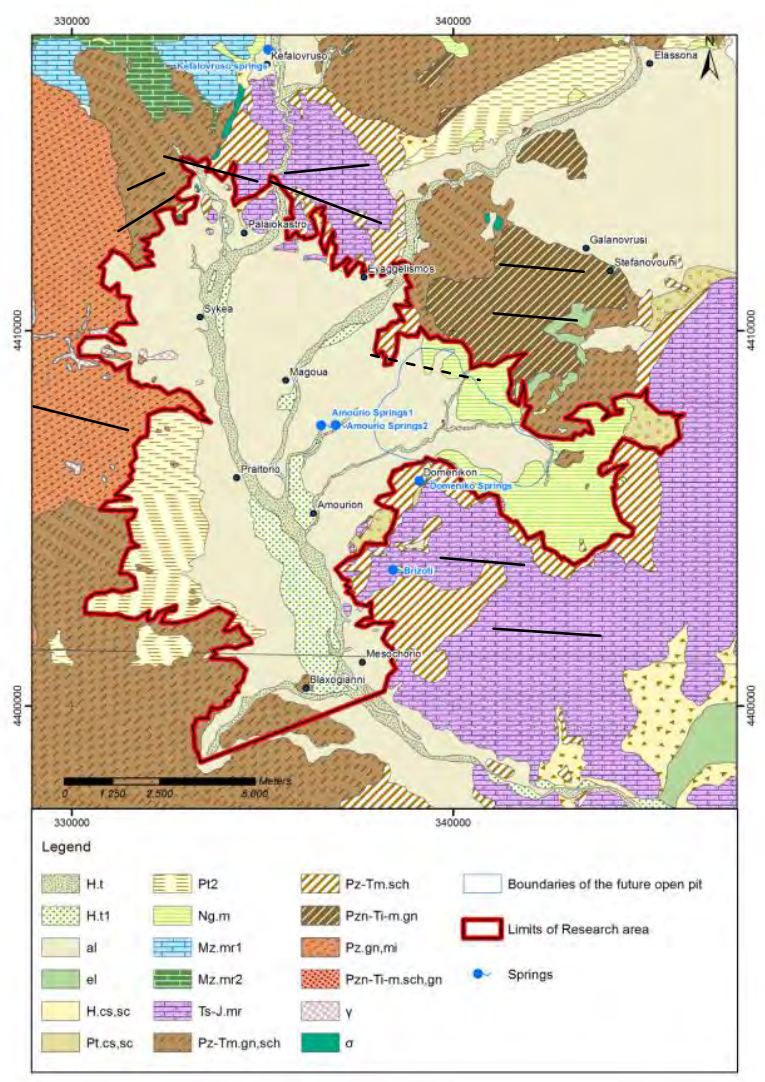

Figure 2 - Geological map of the south part of Elassona basin (Vasileiou, 2011).

\subsection{Kefalovruso Springs}

The karstic aquifer is developed in the carbonate formations of Krania. The average water table elevation is about $256 \mathrm{~m}$ asl, for the period 1988-1992 (Manakos, 1999). The infiltration from the precipitation is the main recharge for this aquifer. Deskati and Paliomantano streams run off the karstic mass and the percolation through them recharges additionally the karstic aquifer.

In 1962, a low dam was constructed at a distance of 20 meters from the main discharge points and an artificial lake was created that covers approximately an area of $3000 \mathrm{~m}^{2}$. The basement of the dam and the lake consist of impermeable Neogene clay formations.

The water discharge through the dam's extractor ends up in a canal, leading to the river Boulgaris. The villages of Kefalovruso, Valanida, Paleokastro and Sukea are supplied with water from the discharge of Kefalovruso springs. The karstic aquifer is exploited by pumping drills, at the upper area of the discharge point. The water flows naturally, through channels, to Paleokastro and Sukea.

The tectonic settings of the marbles formations in the area are the main reason for the existence of these springs, as the groundwater flow blocked by almost impermeable formations such as the crystalline schist, gneiss of Pelagonian zone and sediments with clay and marl composition, of Neogene and Quartenary.

The contact between marbles and schists in the discharge points is a result of the area's tectonism during Miocene (at the end of tectonic movements, the Pelagonian had overthrusted to Krania marbles). 
The springs occur, due to the fault which is located, in a distance of 2,5 Km south of their location (Manakos \&Tasios, 1998). The fault cannot be seen in the discharge points, as it is filled with Neogene and Olocene deposits.

\section{Materials and Methods}

\subsection{Hydrological Data of Amourio}

The available time series of monthly water measurements cover the period of 1972-2008 (Region of Thessaly-Department, Ministry of Agriculture). According to these data the average discharge of the springs was estimated at about $0,417 \mathrm{~m}^{3} / \mathrm{s}$. The minimum value, for the period of 35 years was measured in August $1990\left(0.003 \mathrm{~m}^{3} / \mathrm{s}\right)$ and the maximum in April $1987\left(2,767 \mathrm{~m}^{3} / \mathrm{s}\right)$. The average scaling value for July is about $0,40 \mathrm{~m}^{3} / \mathrm{s}$ and for August about $0,362 \mathrm{~m}^{3} / \mathrm{s}$. During summer, while the irrigational needs are increased, the discharge of the springs is almost concurred with the average scaling. This fact is significant and rare for Greece (Vasileiou, 2011).

Another interesting data for the springs is the low ratio between the maximum and minimum discharge value for the whole time period. The small fluctuation among the average monthly discharges proves the good regulation of the aquifer. In 1990, this ratio was higher than the others, probably due to the extended dry period (1988-1990) that was recorded by the nearest meteorological station of Magoula. In this period, the annual precipitation was estimated in half of the value of the average annual rainfall $(445,5 \mathrm{~mm})$, in the same station (Vasileiou, 2011).

The maximum average monthly discharges are recorded in April $\left(0,50 \mathrm{~m}^{3} / \mathrm{sec}\right)$ and the minimum in November $\left(0,31 \mathrm{~m}^{3} / \mathrm{sec}\right)$ (Table 1). Figure 3, presents the annual changes of springs discharge, where the downward trend is obvious through the last 35 years. Only in the years of 1982, 1987, 1996, 1997, high values were observed. The average annual discharge was estimated at about 13 $\mathrm{x} 10^{6} \mathrm{~m}^{3}$. The flow is continuous, but the discharge is often low, during this time. The flood runoff $\left(2,77 \mathrm{~m}^{3} / \mathrm{sec}\right)$ in April of 1987 , was in instant correlation with the precipitation in that period (approximately $671 \mathrm{~mm}$ of rainfall in 1987, $90 \mathrm{~mm}$ in March of the same year and 57,40 $\mathrm{mm}$ in April at Magoula station), which was very high and extreme in comparison to the values of the other years (Vasileiou,2011).

Specifically, on August of 1996, the high discharge value must be correlated with the increased rainfall of that month $(71 \mathrm{~mm})$ and the previous one $(47,70 \mathrm{~mm})$. These values are high for the summer period in this area.

The average water table measurement in the artificial lake was evaluated at about $0,539 \mathrm{~m}$ (reference level the bottom of the lake). The highest value of water table measurement is about $0,85 \mathrm{~m}$ and the lowest about $0,33 \mathrm{~m}$. There is a wide range between these measurements that is confirmed by the standard deviation of statistical sample which is 0,113 .

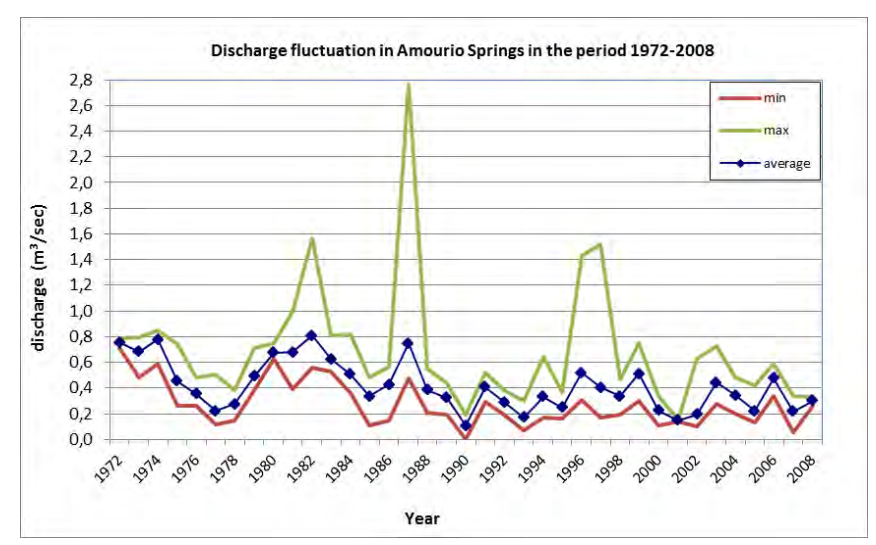

Figure 3 - Diagram of discharge fluctuation for the period 1972-2008, in Amourio springs.

$\underline{\text { XLVII, No } 2-804}$ 
Table 1 - Statistical data for the period 1972-2008, in Amourio springs.

\begin{tabular}{|l|c|c|c|}
\hline Months & $\begin{array}{c}\text { Average Discharge } \\
\mathbf{m}^{\mathbf{3}} / \mathbf{s e c}\end{array}$ & $\begin{array}{c}\text { Minimum Discharge } \\
\mathbf{~ m}^{\mathbf{3}} / \mathbf{s e c}\end{array}$ & $\begin{array}{c}\text { Maximum Discharge } \\
\mathbf{~ m}^{\mathbf{3}} / \mathbf{s e c}\end{array}$ \\
\hline January & 0,39 & 0,14 & 0,72 \\
\hline February & 0,42 & 0,15 & 0,79 \\
\hline March & 0,42 & 0,12 & 0,81 \\
\hline April & 0,50 & 0,12 & $\mathbf{2 , 7 7}$ \\
\hline May & 0,44 & 0,15 & 0,83 \\
\hline June & 0,44 & 0,12 & 0,85 \\
\hline July & 0,40 & 0,04 & 1,43 \\
\hline August & 0,36 & $\mathbf{0 , 0 0 3}$ & 0,99 \\
\hline September & 0,36 & 0,04 & 1,56 \\
\hline October & 0,35 & 0,04 & 0,77 \\
\hline November & 0,31 & 0,06 & 1,52 \\
\hline December & 0,38 & 0,11 & \\
\hline Average & $\mathbf{0 , 4 1}$ & & \\
\hline
\end{tabular}

There is a strong relation between the spring's discharge and the level of water. Figure 4 presents the correlation between the rainfall in Magoula meteorological station and the discharge of Amourio springs. In specific years (1993, 2002 and 2005), when the precipitation was significant, the measured discharges were low. Additionally in the year of 1997 and 2003, even though the rainfall was low, the spring's discharge was high. These deviations increase the possibility that the groundwater recharges by the karstic system of Evaggelismos-Paleokastro as well. This karstic system is developed in higher elevation; therefore the precipitation is higher than Magoula's station.

During the dry periods, when there is no water inflow into the aquifer, the dynamic water reserve from which the spring outflows decreases as a function of time, and the groundwater level declines. Maillet (1905) suggested that the discharge of a spring is a function of the water volume held in storage and described it by the simple exponential equation (Milanovic 1981; Ford \& Williams 2007):

$\mathrm{Qt}=\mathrm{Q}_{0}{ }^{*} \mathrm{e}^{-\mathrm{at}}$

Maillet's (1905) equation recession analysis of the discharges of Amourio springs were performed, and recession coefficients (a) and dynamic volume (storage capacity, Vs) of the aquifer were calculated. The recession (discharge) coefficients of Amourio springs were estimated at a constant value of a $=7,99 \times 10^{-3} \mathrm{day}^{-1}$ and dynamic volume (storage capacity) values are $\mathrm{Vs}=3,51 \times 10^{6} \mathrm{~m}^{3}$. This equation was tested and presented, in this paper, for a period of three years and as the differences among the results was very small, was regarded as graphical errors. These three years had measurements for all the time period and were representative for the precipitation in the area. The system was evaluated as simple and well operated. The discharge of the springs is not directly affected by the monthly variations of the precipitation.

The value of the recession coefficient derives from the hydrogeological characteristics of the aquifer, especially by the effective porosity and transmissivity. Small values of the coefficient indicate very slow drainage of the aquifer with large storage capacity. The springs of this type of aquifer 
are mostly permanent. Large values of the coefficient (the recession curve is steep) indicate rapid drainage through the conduits and little underground storage (Milanovic 1981; Ford \& Williams 2007).

Figure 4 presents the hydrograph of discharge fluctuation in the year of 2005. The red part of the line corresponds to the dry season of the year.

Table 2 - Maillet equation recession analysis in Amourio springs.

\begin{tabular}{|l|l|l|l|}
\hline & $\mathbf{1 9 9 9}$ & $\mathbf{2 0 0 3}$ & $\mathbf{2 0 0 5}$ \\
\hline $\mathrm{a} \mathrm{d}^{-1}$ & $7,99 \times 10^{-03}$ & $3,37 \times 10^{-03}$ & $7,99 \times 10^{-03}$ \\
\hline $\mathrm{W} \mathrm{m}^{3}$ & $3,51 \times 10^{6}$ & $1,56 \times 10^{7}$ & $3,51 \times 10^{6}$ \\
$\mathrm{q}_{\mathrm{o}} \mathrm{m}^{3} / \mathrm{sec}$ & 0,730 & 0,610 & 0,325 \\
\hline
\end{tabular}

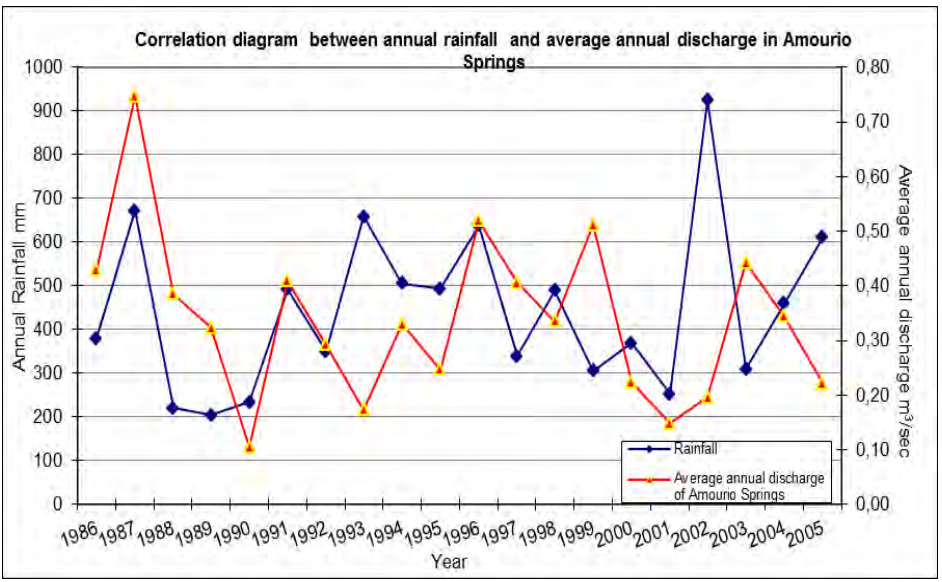

Figure 4 - Correlation diagram of rainfall and discharge of Amourio springs

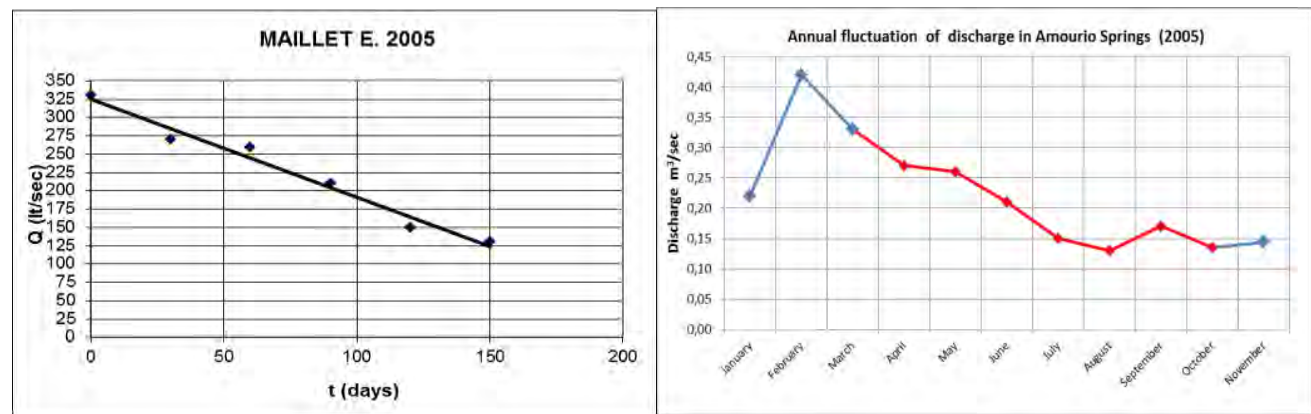

Figure 5 - Hydro-diagram of Maillet for Amourio springs

\subsection{Hydrological Data of Kefalovruso}

The average discharge of Kefalovruso spring for the period 1972-2008, was estimated at $1,277 \mathrm{~m}^{3} / \mathrm{s}$. The average maximum spring's discharge was measured in April $\left(1,8 \mathrm{~m}^{3} / \mathrm{s}\right)$, the minimum in August of $2001\left(0,12 \mathrm{~m}^{3} / \mathrm{s}\right)$ and the maximum in December of $1982\left(5,120 \mathrm{~m}^{3} / \mathrm{s}\right)$. The average discharge for July was measured at $1,19 \mathrm{~m}^{3} / \mathrm{s}$ (although it is a dry season with increased water demands in the area). In the next months, the average monthly discharges are lower, the average minimum value is observed in October $\left(0,683 \mathrm{~m}^{3} / \mathrm{s}\right)$. It increases in November and December, but remaining in low values until June (Vasileiou, 2011).

The ratio of maximum and minimum values is low (average ratio 4,08) for each year, ranging between 1,35 (1972) and 5,33 (1984), that indicates a well regulated aquifer, which is distinguished

$\underline{\text { XLVII. No } 2-806}$ 
by a well interconnected karstic system. The spring's function isn't affected significantly from the pumping and this is proved by the observed small drawdown of the water table (Vasileiou, 2011).

Figure 6 presents, the discharge fluctuation of the springs per time. It is obvious that there is a decrease of flow rate during last 35 years. The spring's discharge is continuous and the annual value is estimated at about $40,27 \times 10^{6} \mathrm{~m}^{3}$. Figure 7 presents the water table fluctuations at the artificial lake. The highest water table level was at $0,62 \mathrm{~m}$ in 1983 and the change was $0,45 \mathrm{~m}$ for the last 35 years (bottom of the lake). The average water table in the lake was estimated at $0,35 \mathrm{~m}$. The combinational diagram shows a strong correlation between rainfall (meteorological station of Giannota) and spring's discharge after 1997.

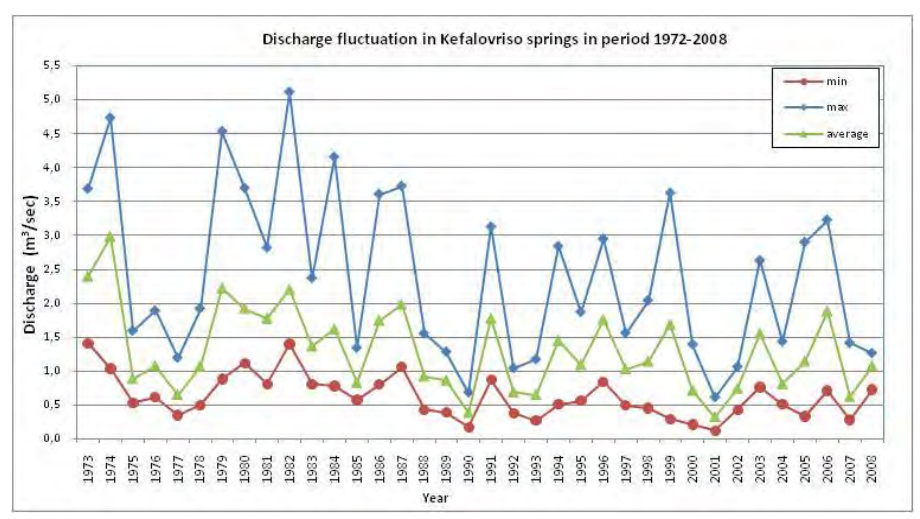

Figure 6 - Diagram of discharge fluctuation for the period 1972-2008, in Kefalovruso springs.

Table 3: Statistical data for the period 1972-2008, in springs of Kefalovruso.

\begin{tabular}{|c|c|c|c|}
\hline Múves & $\begin{array}{c}\text { Average discharge } \\
\left(\mathrm{m}^{3} / \mathrm{sec}\right)\end{array}$ & 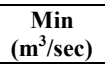 & $\begin{array}{c}\operatorname{Max} \\
\left(\mathrm{m}^{3} / \mathrm{sec}\right)\end{array}$ \\
\hline January & 1,464 & 0,500 & 4,540 \\
\hline February & 1,549 & 0,420 & 2,900 \\
\hline March & 1,769 & 0,480 & 3,700 \\
\hline April & 1,806 & 0,470 & 3,790 \\
\hline May & 1,637 & 0,210 & 3,620 \\
\hline June & 1,657 & 0,140 & 4,740 \\
\hline July & 1,187 & 0,130 & 4,520 \\
\hline August & 0,822 & 0,120 & 4,430 \\
\hline September & 0,816 & 0,170 & 2,880 \\
\hline October & 0,683 & 0,200 & 1,400 \\
\hline November & 0,894 & 0,280 & 2,430 \\
\hline December & 1,040 & 0,400 & 5,120 \\
\hline Average & 1,277 & & \\
\hline
\end{tabular}

Maillet's equation was applied for the karstic spring of Kefalovruso for the dry period of the years 1986, 1994 and 2005, the results are presented in Table 4.The values of the recession coefficients calculated for Kefalovruso springs and small changes in the discharge through the years indicate that the karstic aquifer of Krania has a large storage capacity and the drainage occurs very slowly. The discharges of the springs are not directly affected by the monthly variations of the precipitation. 


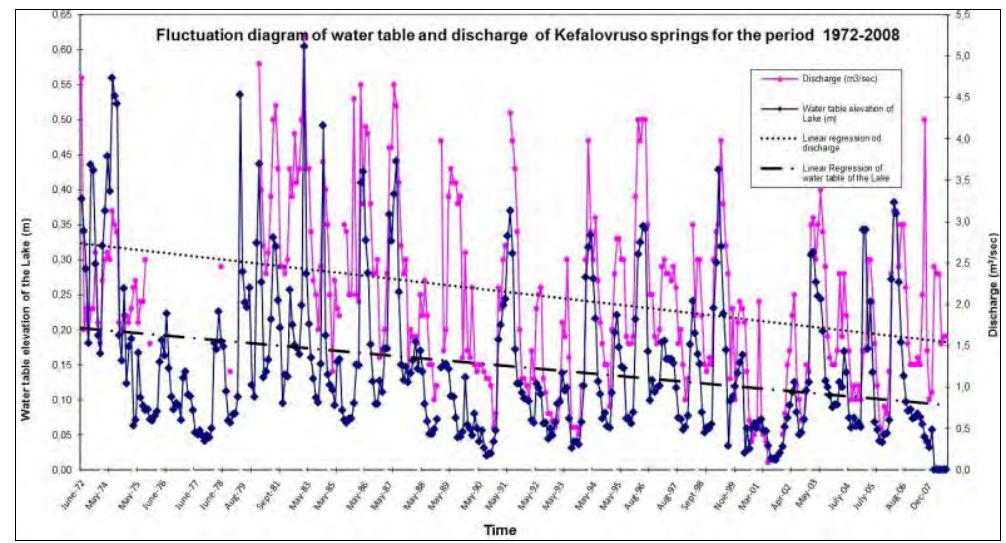

Figure 7: Diagram of water table in the lake and discharge of Kefalovruso springs.

The high values of coefficient $\left(10^{-2}\right)$ indicate a poor operated karstic system and that the drainage occurs very quickly. These values of the recession coefficients are different from the calculated ones $\left(\mathrm{a}=10^{-3}\right)$ by Manakos (1999), for the years 1989, 1990 and 1992. Manakos (1999) mentioned that the karstic spring of Kefalovruso is the main discharge point of the karstic system of Krania

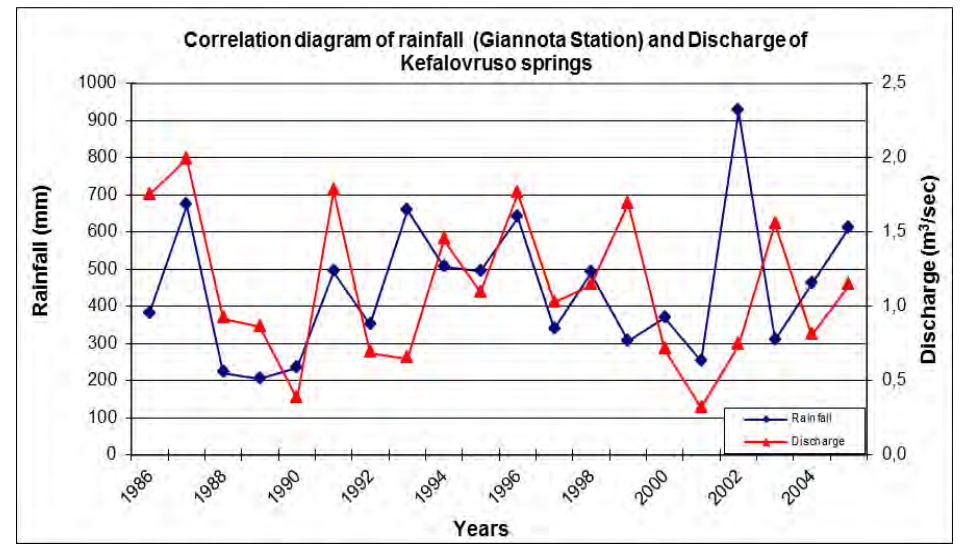

Figure 8 - Diagram of rainfall and discharge in Kefalovruso springs.

According to table 4 , the different values of $\mathrm{q}_{\mathrm{o}}$ and $\mathrm{W}_{\mathrm{o}}$, that were calculated in these three years, are justified by the rainfall recharge fluctuations.

Figure 9 presents the operation of the springs during dry and wet season, where the significant changes of discharge are observed in the year of 2005. The red part of the line represents the dry season for the spring, which is the time period for Maillet equation analysis.

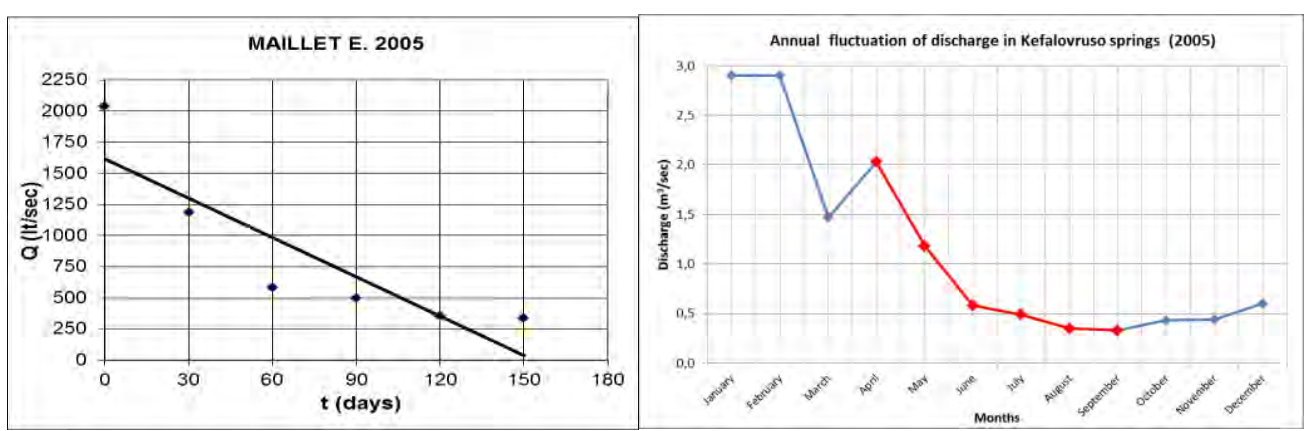

Figure 9 - Hydro-diagram of Maillet.

XLVII. No $2-808$ 
Table 4: Maillet equation recession analysis in Amourio springs.

\begin{tabular}{|c|c|c|c|}
\hline & $\mathbf{1 9 8 6}$ & $\mathbf{1 9 9 4}$ & \multicolumn{1}{c|}{$\mathbf{2 0 0 5}$} \\
\hline $\mathrm{a} \mathrm{d}^{-1}$ & $1,21 \times 10^{-2}$ & $1,20 \times 10^{-2}$ & $1,35 \times 10^{-2}$ \\
\hline $\mathrm{W} \mathrm{m}^{3}$ & $2,46 \times 10^{7}$ & $1,98 \times 10^{7}$ & $1,04 \times 10^{7}$ \\
\hline $\mathrm{q}_{\mathrm{o}} \mathrm{m}^{3} / \mathrm{sec}$ & 3,450 & 2,750 & 1,625 \\
\hline
\end{tabular}

\section{Conclusions-Discussion}

The flow rate and the capacity of Amourio and Kefalovruso springs were examined in this paper. The hydrogeological conditions of Potamia basin are affected significantly from these two springs.

The springs at Kefalovruso are the main discharge point of Krania karstic aquifer. These springs as well as the percolation of Titarisios River are the main recharge a source for the aquifers of the basin's filling (at the northern boundaries of Potamia basin). It was estimated that an average quantity of $28 \times 10^{6} \mathrm{~m}^{3} /$ year percolate in the karstic mass of Krania (Vasileiou, 2011). Significant quantities from the springs flow through channels towards the villages in the north covering their water needs (Sukea, Paleokastro). Additionally, the basin is crossed by Titarisios River (109 x10 $\mathrm{m}^{3} /$ year), which is formed by the conflux of Boulgaris and Elassonitikos rivers. Boulgaris River has an additional supply by Kefalovruso springs and some small torrents in the west boundaries of the area. The recharge of the basin is additionally supported by the infiltration of the rivers. The recharge from Boulgaris and Elassonitikos rivers is rich, as it comes from other hydrological basins in higher elevations, in which the rainfalls are higher (Vasileiou et. al., 2011).

The overlaying marbles of the Pelagonian series are of limited extent and thickness, especially in Evagelismos area and in the basin's basement. The total recharge volume of the marbles was estimated at about $3 \times 10^{6} \mathrm{~m}^{3} /$ year. Therefore they are of minor importance concerning their water storage capacity. The marbles of Paleokastro recharge - Amourio spring and increased their discharge rate. The area has two main characteristics, the extended agricultural activities and the overexploitation of the water resources (for covering irrigation and potable needs). A volume over $9,5 \times 10^{6} \mathrm{~m}^{3} /$ year is being pumped from wells, mainly along Titarisios river and Amourio springs (Vasileiou, 2011).

Based on the piezometric map (Figure 10) of the basin (Vasileiou, 2011), there is rich recharge from Krania marbles at the north, via Kefalovruso springs. The karstic aquifer of Paleokastro contributes a moderate quantity of water to the alluvial aquifer in the north-east part of the basin and to Amourio springs. In the basin two aquifers are developed, the one of them is unconfined the underlying of the lignites. These springs have the most important role to the hydrodynamic conditions of the basin.

In Amourio area the lignite deposit cannot be exploited, because of the hydrogeological and hydrological conditions in this area. The problems concerning the recharge and high hydraulic over heads of the confined aquifer will cause significant difficulties, fact that makes the exploitation of this lignite field financially forbidden (Vasileiou et al., 2011). On the contrary the recharge that comes from the karstic springs of Kefalovruso, doesn't influence directly the mining activity.

Both springs contribute to the recharge of the basin and are the discharge points of two significant aquifer systems. The role of the springs is very important to the rational water management of the basin, as well as for the planning of every mining or other human activity in the area, which can change the water balance. The water capacity and importance for the area must always be under serious consideration. Protection and optimum exploitation of water resources in the area are necessary.

XLVII. No $2-809$ 


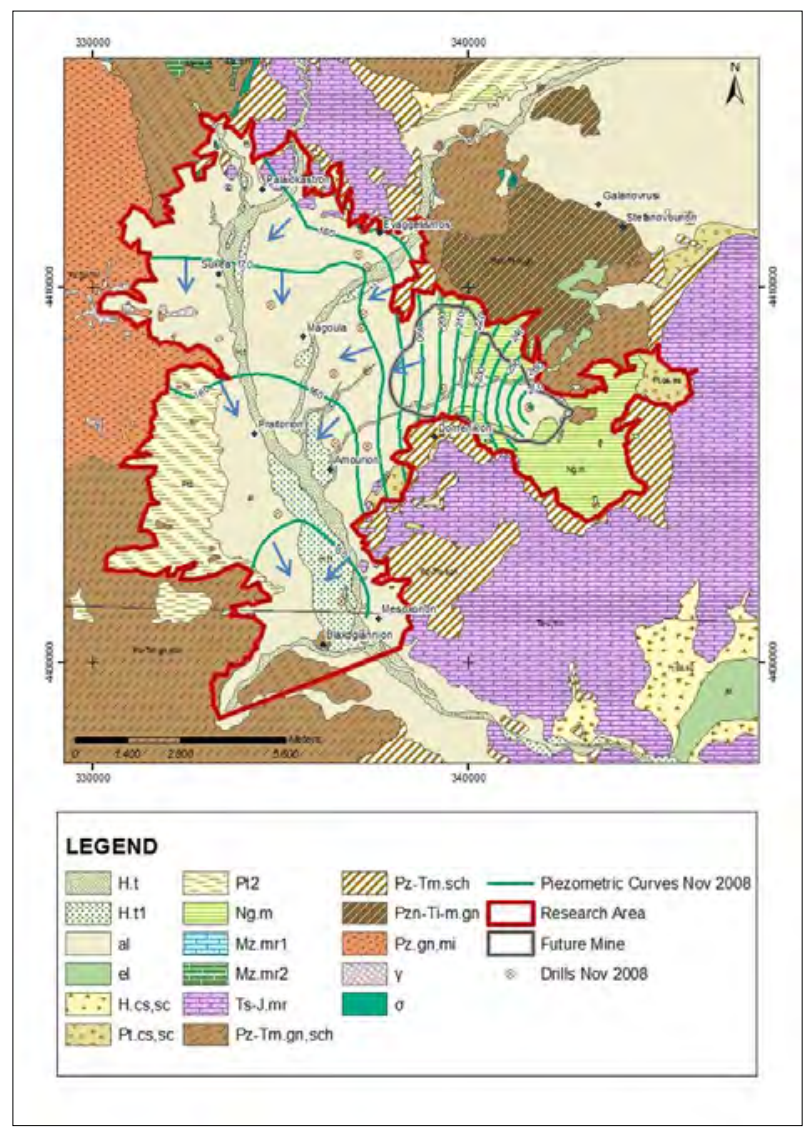

Figure 10: Piezometric map of Potamia basin in November 2008.

\section{References}

Dimitriou D. 1997. The lignite deposit of Domeniko and its importance in energetic economy of our country. IGME Athens.

Ford D. and Williams P. 2007. Karst Hydrogeology and Geomorphology.- John Wiley \& Sons, pp. 562, Chichester.

Maillet E. 1905. Essais d'Hydraulique souterraine et fluviale- Hermann, pp. 218, Paris.

Manakos G.1999. Hydrogeological behaviour and stochastic modeling of the karstic aquifer of Krania in Elassona. Phd thesis in Aristoteleio University of Thessaloniki.

Manakos G. and Tassios G. 1998. Hydrogeological research of the great carbonate masses of Thessaly. The karstic aquifer of Krania, Technical Report, IGME, Thessaloniki.

Milanovic P.T. 1981. Karst Hydrogeology, Water Resources Publications, pp. 434, Littleton.

Region of Thessaly-Department, Ministry of Agriculture

Vasileiou E. 2011. Hydrogeological conditions of Potamia area, in Elassona. The effects of the future exploitation of the two lignite deposits in the water resources. Phd Thesis in NTUA,.

Vasileiou E. and Koumantakis I. 2011. The exploitation of lignite deposits in relation with the surface and groundwater in the mining area. The case study of Potamia basin, in Thessaly, Greece, $11^{\text {th }}$ IMWA Congress-Aachen, Germany 4-11 September. 